\title{
Nondestructive Volume Estimation for Growth Analysis of Eastern-type Muskmelon Ovaries
}

\author{
Sylvie Jenni and Katrine A. Stewart \\ Plant Science Department, Macdonald Campus of McGill University, 21111 \\ Lakeshore road, Sainte-Anne-de-Bellevue, Québec H9X 3V9, Canada
}

Gaétan Bourgeois and Daniel C. Cloutier

Centre for Research and Development in Horticulture, Agriculture and AgriFood Canada, 430 boul. Gouin, Saint-Jean-sur-Richelieu, Québec J3B 3E6, Canada,

Additional index words. cantaloupe, fruit, growth, Cucumis melo

Fruit volume is important for studies of growth and development of muskmelon (Cucumis melo L.) in relation to environmental factors and management practices. Volumes measured by water displacement are precise. However, this method is time-consuming, possibly damaging for the ovaries due to repeated measures over time, and impractical, particularly for measuring many ovaries under field conditions. A nondestructive method was adapted to precisely and rapidly evaluate ovary volume at various phenological stages. This method could be used to study growth and development of eastern-type muskmelon ovaries from anthesis to fruit maturity.

Fruit volume of muskmelon has been estimated from their equatorial diameter by a 4 th order polynomial regression (McGlasson and Pratt, 1963) or from their polar and equatorial diameters taking into account fruit geometry (Currence et al., 1944). McGlasson and Pratt's equation was developed for fruit within a diameter range of 2.8 to $14.7 \mathrm{~cm}$ and cannot be used outside this range. Although Currence et al. (1944) developed their formula from fruit ranging from 8 to $20 \mathrm{~cm}$ in diameter and 9 to $23 \mathrm{~cm}$ in length, these authors took into account the departure of the shape of the fruit from a sphere or an ellipsoid and used a wide

\footnotetext{
Received for publication 25 Jan. 1996. Accepted for publication 11 July 1996. This project was supported by a grant from the Conseil de Recherche en Pêche et Agroalimentaire du Québec. S. Jenni was supported by a Fellowship from the Natural Sciences and Engineering Research Council. We thank one of the anonymous referees who suggested that McGlasson and Pratt's equation might have been misprinted. He felt that the correct equation was: $1 n$ $\mathrm{Y}=1.07934+2.07068 \mathrm{X}-0.10773 \mathrm{X}^{2}-0.00339 \mathrm{X}^{3}$ $-0.000414 \mathrm{X}^{4}$, where $\mathrm{Y}$ is the volume in $\mathrm{mL}$ and $\mathrm{X}$ the equatorial diameter in inches for fruit diameters in the range of 1.12 to 5.78 inches. The cost of publishing this paper was defrayed in part by the payment of page charges. Under postal regulations, this paper therefore must be hereby marked advertisement solely to indicate this fact.
}

range of cultivars. In our work, we propose to extend the applicability of Currence et al.'s formula to growing ovaries.

Our objective was to test Currence et al.'s model for small growing ovaries of easterntype muskmelon outside the range for which it was originally developed, that is, for fruit 0.6 to $17.1 \mathrm{~cm}$ in diameter and 1.1 to $18.6 \mathrm{~cm}$ long. The volume calculated from the length and diameter of fruit at various phenological stages was compared with the volume measured from water displacement.

Three-week-old 'Earligold' muskmelon transplants were planted 1 June 1994 into a sandy loam field covered with 1.2-m-wide black plastic mulch. Water was supplied via drip irrigation lines. Nitrogen was applied at $100 \mathrm{~kg} \cdot \mathrm{ha}^{-1}$ and other nutrients were applied according to soil tests and recommendations (Conseil des Productions Végétales du Québec, 1994). Insect and disease control followed Quebec recommendations. Weeds were controlled manually between the rows. The experiment had three replications of three $8-\mathrm{m}$ rows with only the center row being used experimentally. Plants were spaced at $0.7 \mathrm{~m}$ within and $2.0 \mathrm{~m}$ between rows.

Once a week, one plant in each of the three replications was randomly sampled and cut at the soil level. All perfect flowers and fruit were cut at the base of the pedicel. Polar and equatorial diameters of inferior ovaries were measured using a digital caliper. After the calyx and the corolla were removed, the volume of the ovary or fruit was measured by immersion in a graduated cylinder. In total, 167 ovaries at various phenological stages were measured over 6 weeks. Only one polar diameter was measured because it was very uniform for young immature fruit; this was not true for more mature fruits, which might account for a greater variation in predicting values when larger fruit volumes were estimated. Ovary volume was calculated from polar and equatorial diameters according to formula developed by Currrence et al. (1944): $\mathrm{Y}=\mathrm{K} \mathrm{D} \mathrm{D}^{2} \mathrm{~L} / 1000$ where: $\mathrm{K}=0.1528(\mathrm{D} / \mathrm{L})+0.4152$, if $(\mathrm{D} / \mathrm{L}) \leq 1$ $\mathrm{K}=-0.2204(\mathrm{D} / \mathrm{L})+0.7872$, if $(\mathrm{D} / \mathrm{L})>1$ and $\mathrm{Y}$ is fruit volume $\left(\mathrm{cm}^{3}\right), \mathrm{K}$, a shape factor, $\mathrm{D}$, fruit diameter $(\mathrm{mm})$ and $\mathrm{L}$, fruit length $(\mathrm{mm})$. Most of the range between 0.5 and 17 $\mathrm{cm}$ in ovary diameter and 1 to $19 \mathrm{~cm}$ in ovary length was covered, with a particular emphasis of size around the time of anthesis, when it averaged $0.9 \mathrm{~cm}$ in diameter and $1.5 \mathrm{~cm}$ in length (Fig. 1). A majority $(90 \%)$ of the ovaries were oval shape, with a length/diameter $>1$.

Simple linear regression analysis was performed (SAS, 1986, v. 6.09) between the volume of growing muskmelon ovaries measured by water displacement (actual volume) and the volume measured from ovary length and diameter (Fig. 2). The assumption that predicted value at fruit volume $0 \mathrm{~cm}^{3}$ is $0 \mathrm{~cm}^{3}$ was confirmed, as the intercept of the model was not significantly different from zero at $P \leq$ 0.05 . A second analysis with the intercept fixed at zero resulted in a coefficient of variability of $8.7 \%$, a coefficient of determination of $99.7 \%$ and a slope of 0.984 . Although the slope was close in value to 1.000 , a $t$ test indicated that the slope was significantly different from 1.000 at $\mathrm{P} \leq 0.001$. Therefore, although the prediction of fruit volume using Currence et al.'s model (1944) is accurate for mature fruit, a slight, although significant, correction is suggested to evaluate volume of growing ovaries from eastern-type muskmelon. The cultivar used in this experiment might have accounted for this difference, because eastern types tend to be more oval than western types.

Calculated fruit volume from polar and equatorial diameters provided a good estimate of fruit volume measured by water displacement. Although the equation we used was originally developed for large fruit, it can also be used for developing ovaries. Although Currence et al.'s equation was developed using eastern, western, and honeydew types of melons, it can be easily adapted to specific needs. We suggest to use $\mathrm{Y}=0.984 \mathrm{~K} \mathrm{D}^{2} \mathrm{~L} /$ 1000 for ovaries of eastern-type muskmelon, such as 'Earligold', that are 0.5 to $17 \mathrm{~cm}$ in diameter and 1 to $18 \mathrm{~cm}$ long. This equation allows for rapid, nondestructive, and accurate estimation of growing ovary volume by measuring length and diameter directly in the field.

\section{Literature Cited}

Conseil des Productions Végétales du Québec. 1994. Grille de référence en fertilisation. Agdex 540. Ministère de l'Agriculture, des Pêcheries et de l'Alimentation du Québec.

Currence, T.M., R.E. Lawson, and R.M. Brown. 1944. A rapid method for finding the volume and density of muskmelon fruits. J. Agr. Res. $68: 427-440$

McGlasson, W.B. and H.K. Pratt. 1963. Fruit-set patterns and fruit growth in cantaloupe (Cucumis melo var. reticulatus Naud.). Proc. Amer. Soc. Hort. Sci. 83:495-505.

SAS Institute. 1986. SAS systems for regression. 1986 edition. SAS Inst.Cary, N.C. 